\title{
SURGICAL OUTCOMES AND PROGNOSTIC FACTORS IN PATIENTS WITH SYNCHRONOUS COLORECTAL LIVER METASTASES
}

\author{
Rafael FONTANA'1, Paulo HERMAN², Vincenzo PUGLIESE², \\ Marcos Vinicius PERINI², Fabricio Ferreira COELHO² and Ivan CECCONELLO²
}

\begin{abstract}
Context - Colorectal cancer is the second most prevalent cancer worldwide, and the liver is the most common site of metastases. Surgical resection of colorectal liver metastases provides the sole possibility of cure and the best odds of long-term survival. Objective - To describe surgical outcomes and identify features associated with disease prognosis in patients submitted to synchronous colorectal cancer liver metastasis resection. Methods - Retrospective study of 59 patients who underwent surgery for synchronous colorectal cancer liver metastasis. Actuarial survival and disease-free survival were assessed, depending on the prognostic variable of interest. Results - Postoperative mortality and morbidity rates were $3.38 \%$ and $30.50 \%$ respectively. Five-year disease-free survival was estimated at $23.96 \%$, and 5 -year overall survival, at $38.45 \%$. Carcinoembryonic antigen levels $\geq 50 \mathrm{ng} / \mathrm{mL}$ and presence of three or more liver metastasis were limiting factors for disease-free survival, but did not affect late survival. No patient with liver metastases and extrahepatic disease had disease-free interval longer than 20 months, but this had no significance or impact on long-term survival. None of the prognostic factors assessed had an impact on late survival, although no patients with more than three liver metastases survived beyond 40 months. Conclusion - Although Carcinoembryonic antigen levels and number of metastases are prognostic factors that limit disease-free survival, they had no impact on 5-year survival and, therefore, should not determine exclusion from surgical treatment. Resection is the best treatment option for synchronous colorectal liver metastases, and even for patients with multiple metastases, large tumors and extrahepatic disease, it can provide long-term survival rates over $38 \%$. HEADINGS - Liver neoplasms, surgery. Colorectal neoplasms, surgery. Neoplasm metastasis.
\end{abstract}

\section{INTRODUCTION}

Colorectal cancer (CRC) is the second most prevalent cancer worldwide, being the fourth leading cause of cancer death among men and the fifth among women ${ }^{(14)}$. In the natural history of this neoplasm approximately $60 \%$ of patients treated with curative intent will develop recurrent or metastatic disease, which is well established as the main limiting factor for survival ${ }^{(6)}$.

The liver is the most common site of CRC metastases; however, isolated involvement of the liver as the solitary site of metastasis occurs in approximately $30 \%$ of cases ${ }^{(6,42)}$. In the majority of studies, synchronous metastases - detected simultaneously with the primary tumor or within 1 year of primary tumor resection - account for $25 \%$ to $50 \%$ of cases of colorectal liver metastases (CLM), whereas metachronous progression occurs in approximately $60 \%$ of patients ${ }^{(16)}$
Surgical resection of CLM provides the sole possibility of cure and the best odds of long-term survival ${ }^{(16,22,42)}$. Patients submitted to resection can achieve 5-year survival rates of up to $57 \%$ after resection with low rates of perioperative morbidity and mortality, which has made resection the treatment of choice $^{(22,23,25,44)}$.

Several prognostic factors of long-term survival have been studied in attempt to select patients who will benefit from resection of liver metastases and to propose novel therapies for those at high risk of disease recurrence ${ }^{(33)}$. The prognostic factors associated with overall and disease-free survival most often reported are the presence of lymph node involvement in the vicinity of the primary tumor $(\mathrm{N} 1$ colorectal cancer), the disease-free interval between primary tumor resection and onset of metastases, the size and number of metastases, and serum carcinoembryonic antigen levels ${ }^{(13,41)}$. Among these factors, the diseasefree interval which means the time elapsed between

' Universidade de Caxias do Sul, Faculdade de Medicina, Caxias do Sul, RS, Brasil; ${ }^{2}$ Universidade de São Paulo, Faculdade de Medicina, Departmento de Gastroenterologia, São Paulo, SP, Brasil.

Research performed at: Unidade de Cirurgia Hepática, Departamento de Gastroenterologia, Faculdade de Medicina, Universidade de São Paulo, São Paulo, SP, Brasil. Correspondence: Rafael Fontana. Rua Moreira César, 2715/84 - Centro - 95034-000 - Caxias do Sul, RS, Brasil. E-mail: rafaelfontanamd@gmail.com 
resection of the primary tumor and detection of metastases, particularly synchronous metastases, has been described as a major limiting factor for survival ${ }^{(7,17,31)}$.

Several studies have reported that patients with synchronous CLMs have the poorest prognosis, and that these patients exhibit distinct clinical and pathological characteristics as compared with patients with metachronous metastases ${ }^{(21,43)}$, outlining this group as a distinct patient population and even proposing novel therapeutic approaches ${ }^{(4,38)}$. Therefore, the study of factors associated with better or poorer prognosis exclusively in these patients can play an important role.

The aim of this study was to assess the outcomes of surgical treatment of patients with synchronous colorectal liver metastases and evaluate potential prognostic factors that may influence overall and disease-free survival in this population.

\section{METHODS}

A retrospective study was conducted to identify patients that underwent liver resection for the treatment of CLM from May 1996 to November 2007. From 111 patients submitted to liver resection for colorectal liver metastasis, 59 patients with synchronous metastases (those detected at or within 1 year of primary tumor diagnosis) underwent liver resection with curative intent. Patients with liver metastasis and extrahepatic disease, submitted to complete resection, were also included in the study. All patients were staged with abdominal computed tomography (CT) or magnetic resonance image (MRI) and thorax CT. Positron emission tomography PET/CT was indicated selectively in suspicious extrahepatic disease.

The variables of interest as potential prognostic factors are listed on Table 1.

From the 59 patients, 29 were male and 30 female. Age ranged from 24 to 80 years (mean, 56 years). All patients were submitted to open procedure, followed by a thorough inspection of the abdominal cavity and intra operative ultrasound.

A total of 66 surgeries were performed for resection of liver metastases. Two patients underwent a two-stage, and in five, a second liver resection was performed for the treatment of liver recurrence after hepatectomy. Postoperative mortality was defined as any death occurring within 90 days after surgery.

Three- and five-year disease-free survival and late actuarial survival curves were obtained by the Kaplan-Meier method. The log-rank test was used for comparison of late survival and disease recurrence curves with respect to clinical and pathological variables. The significance level was set at 0.05 . Univariate analysis was performed with the SPSS 8.0 software environment. A Cox logistic regression model was used for multivariate analysis. Variables with a $P$-value $<0.2$ on univariate analysis were carried forward to the multivariate model.

This study was approved by the Research Ethics Committee of the Institution under the number 0902/07.
TABLE 1. Variables of interest for univariate analysis of potential prognostic factors associated with late survival and tumor recurrence

\begin{tabular}{|c|c|c|}
\hline Variable & Category & Distribution (\%) \\
\hline Age & $\begin{array}{l}<70 \text { years } \\
\geq 70 \text { years }\end{array}$ & $\begin{array}{l}79.32 \\
20.33\end{array}$ \\
\hline Primary tumor site & $\begin{array}{l}\text { Colon } \\
\text { Rectal/Rectosigmoid }\end{array}$ & $\begin{array}{l}42.37 \\
57.62\end{array}$ \\
\hline $\begin{array}{l}\text { Primary tumor } \\
\text { lymph nodes }\end{array}$ & $\begin{array}{l}\text { Involved }(\mathrm{N}+) \\
\text { Clean }(\mathrm{N}-)\end{array}$ & $\begin{array}{l}49.15 \\
18.64\end{array}$ \\
\hline $\begin{array}{l}\text { Time to metastasis } \\
\text { development }\end{array}$ & $\begin{array}{l}0 \text { months (with } \\
\text { colorectal tumor) } \\
>0 \text { months (after } \\
\text { colorectal tumor) }\end{array}$ & $\begin{array}{l}64.4 \\
35.6\end{array}$ \\
\hline $\begin{array}{l}\text { Preoperative CEA } \\
\text { level }\end{array}$ & $\begin{array}{l}<50 \mathrm{ng} / \mathrm{dL} \\
\geq 50 \mathrm{ng} / \mathrm{dL}\end{array}$ & $\begin{array}{l}58.22 \\
41.17\end{array}$ \\
\hline Number of lesions & $\begin{array}{l}\text { Solitary metastasis } \\
\text { More than one metastasis }\end{array}$ & $\begin{array}{l}67.8 \\
32.2\end{array}$ \\
\hline Number of lesions & $\begin{array}{l}\text { Three or fewer } \\
\text { More than three }\end{array}$ & $\begin{array}{l}79.66 \\
20.43\end{array}$ \\
\hline Size & $\begin{array}{l}<5 \mathrm{~cm} \\
\geq 5 \mathrm{~cm}\end{array}$ & $\begin{array}{l}54.38 \\
45.62\end{array}$ \\
\hline Blood transfusion & $\begin{array}{l}\text { Yes } \\
\text { No }\end{array}$ & $\begin{array}{l}45.61 \\
54.38\end{array}$ \\
\hline $\begin{array}{l}\text { Extrahepatic } \\
\text { disease }\end{array}$ & $\begin{array}{l}\text { Yes } \\
\text { No }\end{array}$ & $\begin{array}{l}22 \\
88\end{array}$ \\
\hline
\end{tabular}

CEA: Carcinoembryonic antigen

\section{RESULTS}

Unilateral metastases were described in $45.7 \%$ of the cases and lesions larger than $5 \mathrm{~cm}$ were observed in $45.6 \%$. In $32.2 \%$ of the cases two or more lesions were observed; $20.4 \%$ of the cases presented three or more metastases.

We have performed 21 right hemihepatectomies, 5 left hemihepatectomies, 5 right trisectionectomies, 6 left trisectionectomies, 12 segmentectomies and 26 wedge resection. In our series, five patients with purely hepatic recurrent disease diagnosed more than 1 year after primary resection underwent a second wedge resection.

Blood transfusion was necessary in $45 \%$ of the cases and $\mathrm{R} 1$ resections (coincidental or compromised margins) were observed in $13.5 \%$ of the patients. There were two $(3.38 \%)$ postoperative deaths, one of which occurred during a rehepatectomy, thus enabling its inclusion in the sample for analysis. The other death occurred due to liver failure in a patient who underwent extended right hepatectomy and was excluded from analysis of prognostic factors.

Postoperative complications were observed in $30.5 \%$ of patients as follows: biliary fistula in 5; other two had biliary fluid collection drained percutaneously all with good outcome. One patient had a right subphrenic abscess, also drained percutaneously with good outcome. Other patient 
had an acute small bowel obstruction due to adhesions, was reoperated with uneventful outcome. Two patients presented transient renal failure. There were two postoperative deaths $(3.38 \%)$ due to septicemia and liver failure.

Overall survival (OS) at 3 and 5 years was $47.5 \%$ and $38.4 \%$, respectively; median survival was 35 months (Figure 1). Disease-free survival (DFS) at 3 and 5 years was $32.6 \%$ and $23.9 \%$, respectively (median DFS, 31 months). Age, gender, primary tumor location, lymph node status, size of largest metastasis, and transfusion requirements had no significant impact on OS or DFS and, accordingly, were not considered prognostic factors for survival.

Patients with synchronous metastases were divided into two groups: those who had metastases detected at the time of primary tumor diagnosis and those whose metastases developed within a year after colorectal cancer treatment. There were no differences between both groups when considering DFS or OS.

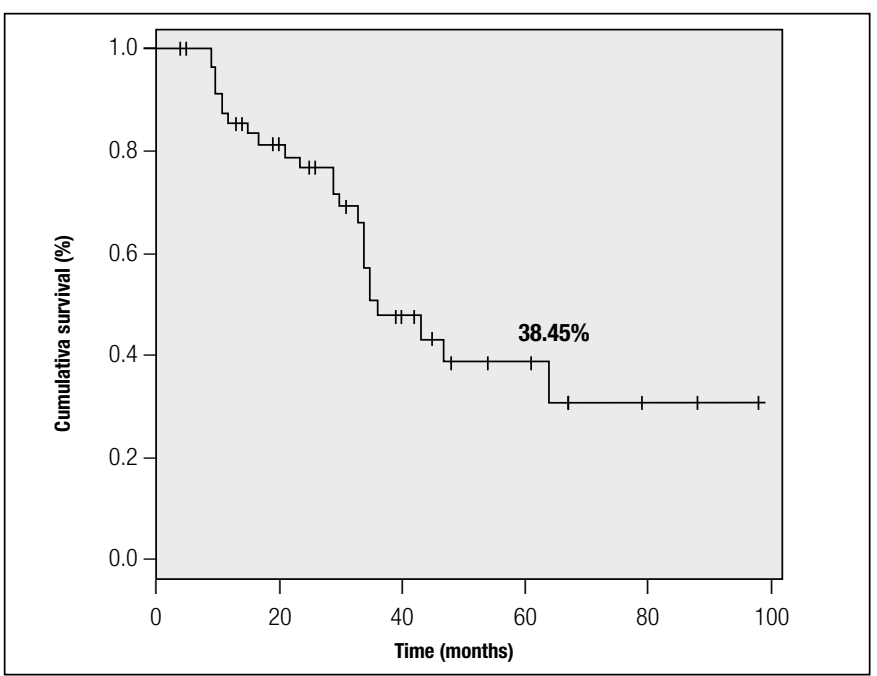

FIGURE 1. Actuarial survival curve

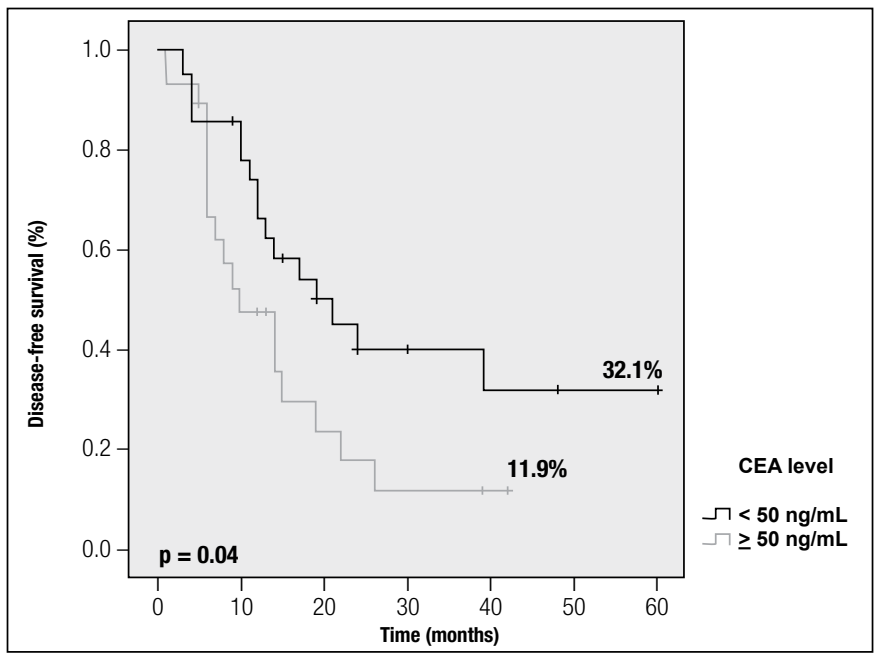

FIGURE 2. Disease-free survival curve, according to carcinoembryonic antigen (CEA) levels
In patients with CEA levels $<50 \mathrm{ng} / \mathrm{mL}, 3$-year DFS was $40.1 \%$, versus $11.9 \%$ in patients with higher levels $(P=$ $0.03)$. Five-year DFS was $32.1 \%$ and $11.9 \%$ respectively in these groups $(P=0.04)$, as shown on Figure 2 . There was no significant impact of CEA levels on OS.

Three and 5-year DFS differed between patients with three or fewer metastases from those with more than three lesions. In these groups, 3-year DFS was $34.6 \%$ and $12.5 \%$, respectively $(P=0.04)$, and 5 -year DFS was, $30.3 \%$ and $12.5 \%$ respectively $(P=0.05)$. Figure 3 shows DFS curves according to the number of metastases. Extrahepatic disease (EHD) was diagnosed and resected in $22 \%$ of patients. Fiveyear overall survival was quite similar between patients with $(32 \%)$ and without $(39.6 \%)$ EHD. There were no significant between-group differences in disease-free survival, although all patients with EHD experienced disease recurrence within 30 months of resection, whereas those without EHD had a $30 \%$ 5-year DFS rate (Figure 4).

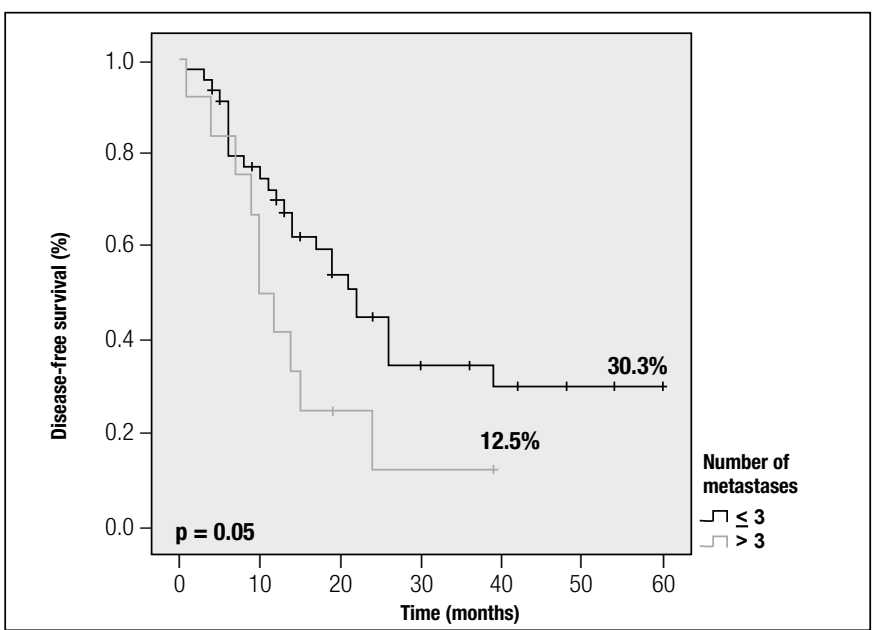

FIGURE 3. Disease-free survival curve, according to the number of metastases

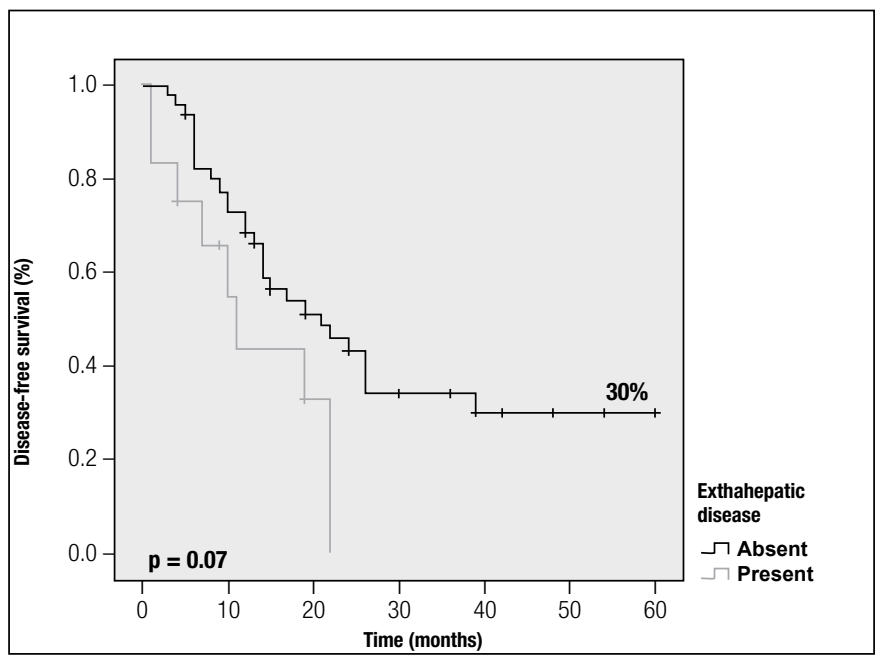

FIGURE 4. Disease-free survival curve according to presence or absence of extrahepatic disease (EHD) 
Multivariate analysis for identification of independent variables associated with disease recurrence revealed that CEA values $>50 \mathrm{ng} / \mathrm{mL}$ was associated with poor prognosis; the risk of disease recurrence was 2.15-fold in this group. No other variables associated presented significant differences.

\section{DISCUSSION}

Therapeutic benefits from colorectal cancer liver metastases resection have been reported since the early 1990s, with 5 -year survival rates ranging from $25 \%$ to $58 \%{ }^{(22,29)}$. Large case series have reported substantial increases in survival among patients undergoing resection as compared with patients in whom resection was not possible or patients with resectable disease in which surgery was withheld for some reason ${ }^{(35)}$.

The current criteria for surgical treatment of CLM are resection of all metastases with clear margins and ability to preserve at least $25 \%$ future liver remnant with good perfusion and adequate venous drainage ${ }^{(12,22)}$. The main contraindications to resection are presence of unresectable extrahepatic disease and impossibility of complete resection of all liver lesions ${ }^{(11)}$ carcinoembryonic antigen.

Since the mid-1970s, the mortality of hepatectomy has declined from rates as high as $20 \%$ to less than $5 \%$ in specialized centers. A systematic review of the short-term and long-term outcomes of CLM resection reported a perioperative mortality rate of $2.8 \%$ being the leading cause of death liver failure followed by bleeding ${ }^{(37)}$. The authors suggest that perioperative mortality should be assessed within the first 90 days after surgery, as many patients developed liver failure and died in the intensive care unit after the 30 th postoperative day ${ }^{(26)}$. In the present study, the perioperative mortality rate was 3.38\%. Currently, it is recommended that planning of any major liver resection include measurement of future liver remnant. If the liver parenchyma is normal, up to $75 \%$ of the liver volume may be resected, whereas patients with hepatic steatosis or those who have received prolonged chemotherapy should be considered as having liver disease ${ }^{(34)}$. In these scenarios, only $60 \%$ of the liver parenchyma may be safely resected ${ }^{(34)}$. Nevertheless, selective portal vein embolization (PVE) can be used to increase the remnant liver volume. PVE induces atrophy of the diseased hemiliver and, consequently, compensatory hypertrophy of the remaining liver segments, both increasing the extent of resectable tissue and improving the safety of surgery ${ }^{(1,3)}$.

CLM resection can be performed safely and with good outcomes in patients over the age of $70^{(2)}$. In our series, patients in this age range had a mortality rate of $4.9 \%$ and a 5 -year overall survival rate of $31.5 \%$ rates similar to those reported in case series of patients with a mean age of less than 70 years $^{(39)}$.

Although advances in surgical techniques and clinical oncology have enabled achievement of long-term survival after resection of colorectal liver metastases, approximately two-thirds of these patients will experience disease recurrence, which constitutes the main limiting factor for survival. The most common site of disease recurrence is the liver alone, followed by extrahepatic sites and, in a minority of patients, both the liver and other structures. Within this context, selected patients whose recurrent disease is limited to the liver can undergo second liver resection, with outcomes similar to those of primary hepatectomy ${ }^{(30)}$.

Even within the context of high recurrence rates, resection is unquestionably the best treatment option for this patients ${ }^{(9)}$. Research on prognostic factors seeks to provide information that might have an impact on the outcomes of surgical treatment, as well as identifying whether novel treatment approaches are required in specific patient subgroups ${ }^{(16)}$. Nearly all studies of survival after resection of CLM have sought to identify prognostic factors associated with surgical outcome ${ }^{(16,25)}$. Primary tumor characteristics, liver metastasis features and treatment-related aspects (both, chemotherapy and surgery) have been the most commonly analyzed factors ${ }^{(6,19)}$. Nevertheless, the true impact of these factors on the outcomes of surgical treatment have yet to be clearly defined, particularly in the specific subgroup of patients with synchronous liver metastases, which are widely known to be associated with worse prognosis ${ }^{(32)}$.

In the present study, we sought to analyze not only the outcomes of liver resection in this specific patient population, but also potential factors that might have an impact on prognosis.

Classically, lymph node involvement of the primary tumor, size of the largest metastasis, number of metastases, serum carcinoembryonic antigen levels, disease-free interval after resection of the primary tumor, and resection margins have been reported as the main factors associated with prognosis ${ }^{(16,25)}$. More recently, response to preoperative (neoadjuvant) chemotherapy has been considered a major factor associated with the outcome of surgical treatment ${ }^{(20,27)}$.

Preoperative carcinoembryonic antigen (CEA) levels have also been associated with prognosis; elevated CEA values have a negative impact on survival estimates ${ }^{(40)}$. In a longterm survival study of patients with resected CLM, there was no survival beyond 40 months in patients with CEA $>15 \mathrm{ng} / \mathrm{mL}$ and no survival beyond 20 months in those with CEA $>200 \mathrm{ng} / \mathrm{mL}^{(24)}$. In another study, the post-hepatectomy disease-free interval was significantly shorter in patients with elevated CEA levels ${ }^{(28)}$. In the present study, elevated CEA levels had a negative impact on disease-free survival, but no impact on overall survival.

The number of liver metastases has been considered a prognostic factor for survival in many studies, although there is no consensus ${ }^{(6,44)}$. Patients with multiple liver metastases often require multiple procedures or two-stage surgeries, as well as adjunctive ablative therapy and perioperative chemotherapy ${ }^{(4)}$. However, evidence suggests that, in patients with more than one liver metastasis, response to chemotherapy and possibility of complete resection are determinants of survival $^{(5,8)}$. In this study, patients with more than three liver metastases had shorter DFS than those patients with three lesions or fewer. Although this finding did not reach statistical significance, it is indicative of greater severity in the subgroup of synchronous metastasis in patients with multiple lesions. 
In the past, large metastases were associated with poor prognosis. However, recent studies have shown that patients with large lesions can experience long-term survival after liver resection ${ }^{(18)}$. Large metastases can make surgery technically challenging and hinder achievement of complete resection (R0), which appears to be one of two key factors associated with prognosis, alongside response to neoadjuvant chemotherapy ${ }^{(27,36)}$.

Patients with CLM and EHD have largely been excluded from survival studies, as their prognosis is usually poor and survival is severely limited ${ }^{(10)}$. However, a recent study has shown that highly selected patients with completely resectable CLM whose EHD is localized and amenable to systemic chemotherapy can, in fact, experience prolonged survival, even if rates are lower than those of patients without $\mathrm{EHD}^{(11)}$. In a study of patients with CLM who had localized EHD and underwent combined surgical and systemic therapy, disease-free and long-term survival rates were similar to those of patients with metastatic disease restricted to the liver ${ }^{(15)} \mathrm{In}$ the present study, there was no disease-free survival beyond 20 months in patients with completely resected EHD, but there was no impact on overall survival.

None of the prognostic factors assessed thus far by a wide range of studies exclude the possibility of resection, but indication of surgical treatment should be interpreted within a clinical context in which other, supplementary treatment modalities are provided. In our experience, for instance, patients with multiple synchronous metastases or synchronous metastases and extrahepatic disease did not experience long-term DFS, which highlights the need for other forms of therapy in addition to surgical treatment.

\section{CONCLUSION}

We must stress that radical surgical resection is the best treatment option for synchronous colorectal liver metastases, as it can provide long-term survival in over one-third of patients and can even be curative in selected cases. In our series, which included many patients with multiple metastases, large tumors and even extrahepatic disease, all considered determinants of unfavorable prognosis; the 5-year survival rate exceeded $38 \%$. This clearly shows that treatment of colorectal liver metastases, when carried out in a specialized center with a multidisciplinary approach, can provide good outcomes even in patient populations with advanced and aggressive disease.

Fontana R, Herman P, Pugliese V, Perini MV, Coelho FF, Cecconello I. Resultados do tratamento cirúrgico e de estudo dos fatores prognósticos em pacientes com metástases hepáticas sincrônicas do câncer colorretal. Arq Gastroenterol. 2014,51(1):4-9.

RESUMO - Contexto - O câncer colorretal é o segundo câncer mais prevalente no mundo e, o fígado é o principal local das metástases. A ressecção cirúrgica da metástases hepáticas colorretais proporciona a única possibilidade de cura e as melhores chances de sobrevida a longo prazo. Objetivo - Avaliar os resultados do tratamento cirúrgico e identificar fatores associados ao prognóstico da doença em pacientes com metástases hepáticas sincrônicas de câncer colorretal submetidos à ressecção. Método - Estudo retrospectivo de 59 pacientes submetidos à ressecção de metástases hepáticas sincrônicas do câncer colorretal, visando à identificação de fatores relacionados ao prognóstico. Foram estudadas a sobrevida atuarial e sobrevida livre de doença, conforme as variáveis. Resultados - A mortalidade e morbidade pós-operatórias foram de 3,38\%, e 30,50\%, respectivamente. A sobrevida livre de doença estimada em 5 anos foi de 23,96\%, e a sobrevida tardia, no mesmo período, foi de 38,45\%. O valor do antígeno cárcino-embrionário igual ou superior a $50 \mathrm{ng} / \mathrm{mL}$ e o número de metástases maior que três representaram fatores prognósticos limitantes da sobrevida livre de doença, porém sem interferir na sobrevida tardia. Pacientes com metástases hepáticas e doença extra-hepática, submetidos à ressecção, não apresentaram sobrevida livre de doença acima de 20 meses, porém sem significância e sem impacto na sobrevida a longo prazo. Nenhum dos fatores prognósticos estudados interferiu na sobrevida tardia, porém não foi observada sobrevida além de 40 meses em pacientes com mais de três metástases hepáticas. Conclusão - Apesar do valor do antígeno cárcino-embrionário e do número de metástases representarem fatores prognósticos limitantes da sobrevida livre de doença, não interferiram na sobrevida em 5 anos. Portanto, não representam fatores de exclusão ao tratamento cirúrgico, podendo atingir sobrevida a longo prazo. A ressecção é o melhor tratamento para as metástases sincrônicas de câncer colorretal e, mesmo em pacientes com múltiplas metástases, grandes tumores e doença extra-hepática, pode propiciar sobrevida tardia em mais de $38 \%$ dos casos.

DESCRITORES - Neoplasias hepáticas, cirurgia. Neoplasias colorretais, cirurgia. Metástase neoplásica. 


\section{REFERENCES}

1. Abdalla EK, Hicks ME, Vauthey JN. Portal vein embolization: rationale, technique and future prospects. Br J Surg 2001;88:165-75.

2. Adam R, Frilling A, Elias D, Laurent C, Ramos E, Capussotti L, Poston GJ, Wicherts DA, de Haas RJ. Liver resection of colorectal metastases in elderly patients. Br J Surg. 2010;97:366-76.

3. Adam R, Laurent A, Azoulay D, Castaing D, Bismuth H. Two-stage hepatectomy: A planned strategy to treat irresectable liver tumors. Ann Surg. 2000;232:777-85.

4. Adam R, Pascal G, Castaing D, Azoulay D, Delvart V, Paule B, Levi F, Bismuth $\mathrm{H}$. Tumor progression while on chemotherapy: a contraindication to liver resection for multiple colorectal metastases? Ann Surg. 2004;240:1052-61; discussion 1061-4.

5. Allen PJ, Kemeny N, Jarnagin W, DeMatteo R, Blumgart L, Fong Y. Importance of response to neoadjuvant chemotherapy in patients undergoing resection of synchronous colorectal liver metastases. J Gastrointest Surg. 2003;7:109-115; discussion 116-7.

6. Altendorf-Hofmann A, Scheele J. A critical review of the major indicators of prognosis after resection of hepatic metastases from colorectal carcinoma. Surg Oncol Clin N Am. 2003;12:165-92, xi.

7. Benoist S, Pautrat K, Mitry E, Rougier P, Penna C, Nordlinger B. Treatmen strategy for patients with colorectal cancer and synchronous irresectable liver metastases. Br J Surg. 2005;92:1155-60.

8. Blazer DG, 3rd, Kishi Y, Maru DM, Kopetz S, Chun YS, Overman MJ, Fogelman D, Eng C, Chang DZ, Wang H, Zorzi D, Ribero D, Ellis LM, Glover KY, Wolff RA, Curley SA, Abdalla EK, Vauthey JN. Pathologic response to preoperative chemotherapy: a new outcome end point after resection of hepatic colorectal metastases. J Clin Oncol. 2008;26:5344-51.

9. Brouquet A, Vauthey JN, Badgwell BD, Loyer EM, Kaur H, Curley SA, Abdalla EK. Hepatectomy for recurrent colorectal liver metastases after radiofrequency ablation. Br J Surg. 2011;98:1003-9.

10. Cady B, McDermott WV. Major hepatic resection for metachronous metastases from colon cancer. Ann Surg. 1985;201:204-09.

11. Carpizo DR, D'Angelica M. Liver resection for metastatic colorectal cancer in the presence of extrahepatic disease. Lancet Oncol. 2009;10:801-9.

12. Charnsangavej C, Clary B, Fong Y, Grothey A, Pawlik TM, Choti MA. Selection of patients for resection of hepatic colorectal metastases: expert consensus statement. Ann Surg Oncol. 2006;13:1261-8.

13. Cohen MP, Machado MA, Herman P. The impact of intra operative ultrasound in metastases liver surgery. Arq Gastroenterol. 2005;42:206-12.

14. McMillan DC, McArdle CS. Epidemiology of colorectal liver metastases. Surg Oncol. 2007;16:3-5.

15. Elias D, Sideris L, Pocard M, Ouellet JF, Boige V, Lasser P, Pignon JP, Ducreux M. Results of R0 resection for colorectal liver metastases associated with extrahepatic disease. Ann Surg Oncol. 2004;11:274-80.

16. Fong Y, Fortner J, Sun RL, Brennan MF, Blumgart LH. Clinical score for predicting recurrence after hepatic resection for metastatic colorectal cancer: analysis of 1001 consecutive cases. Ann Surg. 1999;230:309-18; discussion 318-21.

17. Fujita S, Akasu T, Moriya Y. Resection of synchronous liver metastases from colorectal cancer. Jpn J Clin Oncol. 2000;30:7-11.

18. Hamady ZZ, Malik HZ, Finch R, Adair R, Al-Mukhtar A, Prasad KR, Toogood GJ, Lodge JP. Hepatic resection for colorectal metastasis: impact of tumour size. Ann Surg Oncol. 2006;13:1493-9.

19. Kopetz S, Chang GJ, Overman MJ, Eng C, Sargent DJ, Larson DW, Grothey A, Vauthey JN, Nagorney DM, McWilliams RR. Improved survival in metastatic colorectal cancer is associated with adoption of hepatic resection and improved chemotherapy. J Clin Oncol. 2009;27:3677-83.

20. Kornprat P, Jarnagin WR, Gonen M, DeMatteo RP, Fong Y, Blumgart LH, D'Angelica M. Outcome after hepatectomy for multiple (four or more) colorectal metastases in the era of effective chemotherapy. Ann Surg Oncol. 2007;14:1151-60.

21. Lambert LA, Colacchio TA, Barth RJ, Jr. Interval hepatic resection of colorecta metastases improves patient selection. Arch Surg. 2000;135:473-9; discussion 479-80.

22. Lupinacci RM, Coelho FF, Perini MV, Lobo EJ, Ferreira FG, Szutan LA, Lopes GJ, Herman P; Clube do Fígado de São Paulo. Manejo atual das metástases hepáticas de câncer colorretal. Recomendações do Clube do Fígado de São Paulo. Rev Col Bras Cir. 2013;40:251-60.

23. Machado MA, Machado MC, Herman P. Hepatic bisegmentectomy 7-8 for a colorectal metastasis. Eur J Surg Oncol. 2006;32:813.

24. Mann CD, Metcalfe MS, Leopardi LN, Maddern GJ. The clinical risk score: emerging as a reliable preoperative prognostic index in hepatectomy for colorectal metastases. Arch Surg. 2004;139:1168-72.

25. Minagawa M, Yamamoto J, Kosuge T, Matsuyama Y, Miyagawa S, Makuuch M. Simplified staging system for predicting the prognosis of patients with resectable liver metastasis: development and validation. Arch Surg. 2007;142:269-76; discussion 277 .
26. Mullen JT, Ribero D, Reddy SK, Donadon M, Zorzi D, Gautam S, Abdalla EK, Curley SA, Capussotti L, Clary BM, Vauthey JN. Hepatic insufficiency and mortality in 1,059 noncirrhotic patients undergoing major hepatectomy. J Am Coll Surg. 2007;204:854-62; discussion 862-4.

27. Nordlinger B, Sorbye H, Glimelius B, Poston GJ, Schlag PM, Rougier P, Bechstein WO, Primrose JN, Walpole ET, Finch-Jones M, Jaeck D, Mirza D, Parks RW,Collette L, Praet M, Bethe U, Van Cutsem E, Scheithauer W, Gruenberge T; EORTC Gastro-Intestinal Tract Cancer Group; Cancer Research UK; Arbeitsgruppe Lebermetastasen und-tumoren in der Chirurgischen Arbeitsgemeinschaf Onkologie (ALM-CAO); Australasian Gastro-Intestinal Trials Group (AGITG); Fédération Francophone de Cancérologie Digestive (FFCD). Perioperative chemotherapy with FOLFOX4 and surgery versus surgery alone for resectable liver metastases from colorectal cancer (EORTC Intergroup trial 40983): a randomised controlled trial. Lancet. 2008;371:1007-16.

28. Oussoultzoglou E, Rosso E, Fuchshuber P, Stefanescu V, Diop B, Giraudo G, Pessaux P, Bachellier P, Jaeck D. Perioperative carcinoembryonic antigen measurements to predict curability after liver resection for colorectal metastases: a prospective study. Arch Surg. 2008;143:1150-8; discussion 1158-9.

29. Pawlik TM, Scoggins CR, Zorzi D, Abdalla EK, Andres A, Eng C, Curley SA, Loyer EM, Muratore A, Mentha G, Capussotti L, Vauthey JN. Effect of surgical margin status on survival and site of recurrence after hepatic resection for colorectal metastases. Ann Surg. 2005;241:715-22, discussion 722-4.

30. Petrowsky H, Gonen M, Jarnagin W, Lorenz M, DeMatteo R, Heinrich S, Encke A, Blumgart L, Fong Y. Second liver resections are safe and effective treatmen for recurrent hepatic metastases from colorectal cancer: a bi-institutional analysis. Ann Surg. 2002;235:863-71.

31. Reddy SK, Barbas AS, Clary BM. Synchronous colorectal liver metastases: is it time to reconsider traditional paradigms of management? Ann Surg Oncol. 2009; 16:2395-410.

32. Reddy SK, Zorzi D, Lum YW, Barbas AS, Pawlik TM, Ribero D, Abdalla EK, Choti MA, Kemp C, Vauthey JN, Morse MA, White RR, Clary BM. Timing of multimodality therapy for resectable synchronous colorectal liver metastases: a retrospective multi-institutional analysis. Ann Surg Oncol. 2009;16:1809-19.

33. Ribeiro HS, Stevanato-Filho PR, Costa Jr WL, Diniz AL, Herman P, Coimbra FJ. Prognostic factors for survival in patients with colorrectal liver metastases: experience of single brazilian cancer center. Arq Gastr. 2012;49:266-72.

34. Robinson S, Manas DM, Pedley I, Mann D, White SA. Systemic chemotherapy and its implications for resection of colorectal liver metastasis. Surg Oncol. 2011;20:57-72.

35. Scheele J, Altendorf-Hofmann A. Resection of colorectal liver metastases. Langenbecks Arch Surg. 1999;384:313-27.

36. Schindl M, Wigmore SJ, Currie EJ, Laengle F, Garden OJ. Prognostic scoring in colorectal cancer liver metastases: development and validation. Arch Surg. 2005;140:183-9.

37. Simmonds PC, Primrose JN, Colquitt JL, Garden OJ, Poston GJ, Rees M. Surgica resection of hepatic metastases from colorectal cancer: a systematic review of published studies. Br J Cancer. 2006;94:982-99.

38. Tanaka K, Adam R, Shimada H, Azoulay D, Levi F, Bismuth H. Role of neoadjuvant chemotherapy in the treatment of multiple colorectal metastases to the liver. Br J Surg. 2003;90:963-9.

39. Temple LK, Hsieh L, Wong WD, Saltz L, Schrag D. Use of surgery among elderly patients with stage IV colorectal cancer. J Clin Oncol. 2004;22:3475-84

40. Thomas P, Forse RA, Bajenova O. Carcinoembryonic antigen (CEA) and its receptor hnRNP M are mediators of metastasis and the inflammatory response in the liver. Clin Exp Metastasis. 2011;28:923-32.

41. Viana EF, Herman P, Siqueira SC, Taka T, Carvalho P, Coelho FF, Pugliese V, Saad WA, D'Albuquerque LA. Lymphadenectomy in colorectal cancer liver metastases resection: incidence of hilar lymph nodes micrometastasis. J Surg Oncol. 2009; 100:534-7.

42. Wagner JS, Adson MA, Van Heerden JA, Adson MH, Ilstrup DM. The natura history of hepatic metastases from colorectal cancer. A comparison with resective treatment. Ann Surg. 1984;199:502-8.

43. Weber JC, Schneider A, Rohr S, Nakano H, Bachellier P, Mechine A, Hamel G, Kanor M, Chenard MP, Gaub MP, Oudet P, Meyer C, Jaeck D. Analysis of allelic imbalance in patients with colorectal cancer according to stage and presence of synchronous liver metastases. Ann Surg. 2001;234:795-802 discussion 802-3.

44. Weber SM, Jarnagin WR, DeMatteo RP, Blumgart LH, Fong Y. Survival after resection of multiple hepatic colorectal metastases. Ann Surg Oncol. 2000;7 $643-50$

Received 24/9/2013 Accepted 25/10/2013

\section{ERRATUM}

Arq. Gastroenterol. 2014;51(1):4-9. Fontana R, Herman P, Pugliese V, Perini MV, Coelho FF, Cecconello I. Surgical outcomes and prognostic factors in patients with synchronous colorectal liver metastases

Which was read the names of the authors of "Paulo Hermam" and "Fabricio Ferreira Velho" was corrected to "Paulo Herman" and "Fabricio Ferreira Coelho" 